\title{
Homocysteine May Contribute to Pathogenesis of RNA Damage in Brains with Alzheimer's Disease
}

\author{
Chiaki Isobe $^{a, b}$ Takashi Abe $^{b}$ Yasuo Terayamab \\ ${ }^{a}$ Department of Neurology, Chitose Daiichi Hospital, Chitose, and b Department of Neurology, Iwate Medical \\ University, Morioka, Japan
}

\section{Key Words}

Alzheimer's disease $\cdot$ Homocysteine, free $\cdot$ Homocysteine, total $\cdot 8$-Hydroxyguanosine $\cdot$ Cerebrospinal fluid

\begin{abstract}
Background: The pathogenesis of Alzheimer's disease (AD) is related to homocysteine $(\mathrm{HC})$, but the details are unknown. Objective: We aimed to measure the cerebrospinal fluid (CSF) concentrations of 8-hydroxyguanosine (8-OHG), considering RNA oxidative damage marker, free $\mathrm{HC}$ and total $\mathrm{HC}$ in the CSF of patients with AD and in normal control subjects. Method and Patients: Subjects were 18 untreated patients with $A D(M / F=7 / 11)$ and 15 age-matched controls $(M / F=$ 9/6), with a mean age $\pm S D$ of $67.4 \pm 5.0$ years for patients and of $65.7 \pm 9.2$ years for controls. The concentrations of free $\mathrm{HC}$, total $\mathrm{HC}$ and 8-OHG in the CSF of AD patients were measured by high-performance liquid chromatography using an electrochemical detector. The control subjects were neurologically normal patients who underwent lumbar spinal anesthesia for minor surgery. Results: Total HC and 8OHG concentrations were significantly increased, and there was a significant positive correlation between total $\mathrm{HC}$ and 8-OHG concentrations. However, the concentration of 8$\mathrm{OHG}$ in the CSF showed no correlation with 8-OHG in serum
\end{abstract}

and was not significantly altered in AD patients. Conclusion: These results suggest that total $\mathrm{HC}$ and $8-\mathrm{OHG}$ are positively correlated and may be related to $A D$ pathogenesis due to RNA-associated oxidative damage linked to total HC.

Copyright $\odot 2009$ S. Karger AG, Basel

\section{Introduction}

Alzheimer's disease (AD) is a progressive neurodegenerative disorder that represents the most common form of dementia. The pathogenesis of $\mathrm{AD}$ has been linked to homocysteine (HC), but the details are unknown [1].

$\mathrm{HC}$ is an amino acid that contains an SH group and is generated from the metabolism of methionine in the sulfur-containing amino acid as well as cysteine. Oxidative stress due to excessive oxidation, resulting from the production of free radicals upon oxidation of $\mathrm{HC}$, may lead to cell damage $[2,3]$. Most $\mathrm{HC}$ in plasma is of the oxidized type, and $70-80 \%$ of the $\mathrm{HC}$ is bound to albumin. The remaining $20-30 \%$ exist as total $\mathrm{HC}$ in the reduced $\mathrm{HC}$ form (sulfhydryl form) and in the oxidized form, and as a mixed disulfide in HC-cysteine and other such combinations. Free HC, i.e. the reduced type, comprises only about $1 \%$ of total HC [4] (fig. 1).

\section{KARGER}

Fax +4161306 1234 E-Mail karger@karger.ch www.karger.com

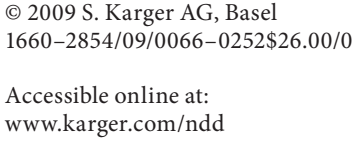




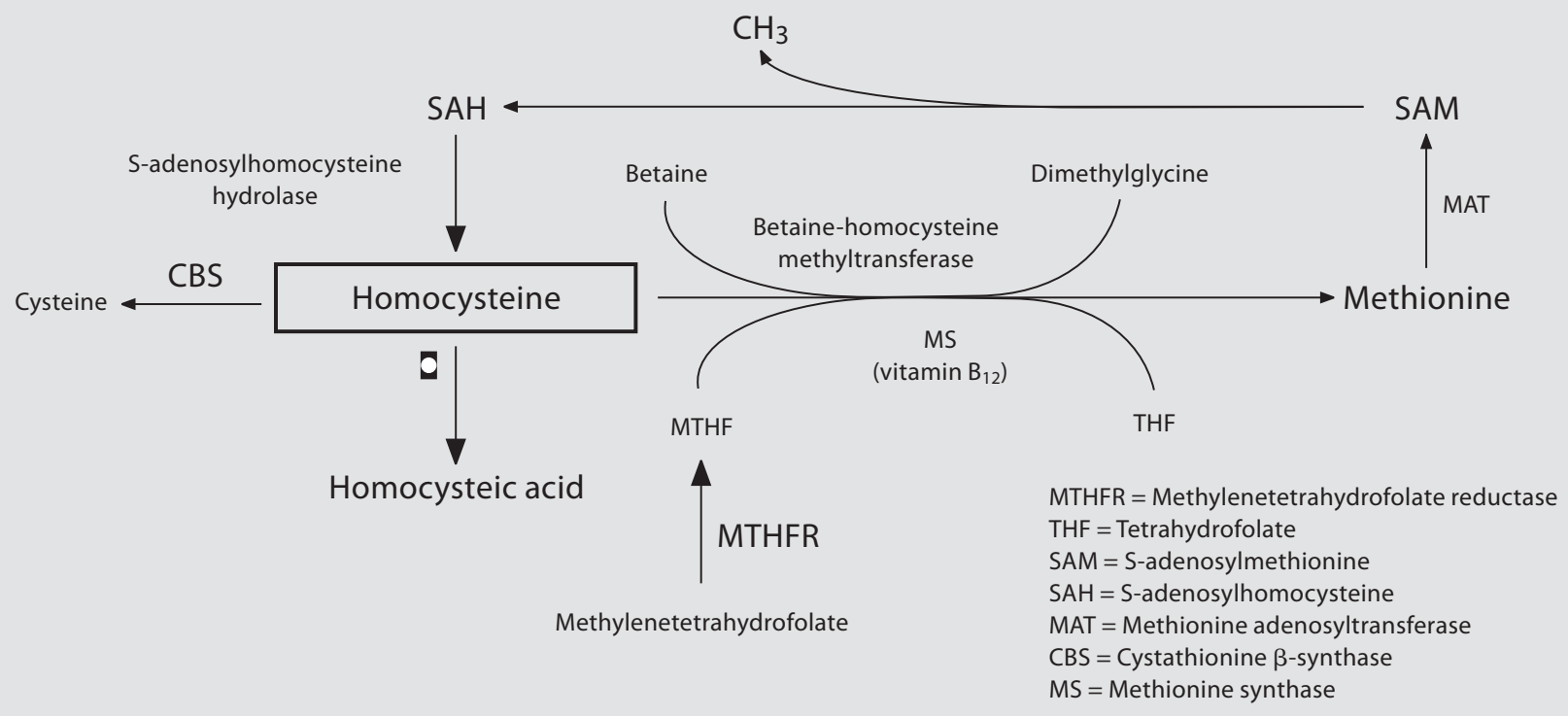

Fig. 1. Synthesis and metabolic pathway associated with HC. Partially revised version of Parnetti et al. [5].

Using mouse models of AD, Kruman et al. [6] recently reported that $\mathrm{HC}$ promotes neurodegeneration in the hippocampus. Previous studies have identified a point mutation from $\mathrm{C}$ to $\mathrm{T}$ in the 677 th nucleoside (C667T) in the methylenetetrahydrofolate reductase (MTHFR) gene. Enzyme activity has also been shown to change due to MTHFR gene polymorphisms, and the plasma total HC concentration is high in polymorphic homo $(\mathrm{T} / \mathrm{T})$ individuals [7]. Plasma total $\mathrm{HC}$ concentrations increase with age and, thus, the relationship between the pathogenesis of $\mathrm{AD}$ and $\mathrm{HC}$ is under investigation [8]. Studies have also suggested that plasma total HC is significantly higher in $\mathrm{AD}$ patients than in normal controls, and a significant correlation has been found between plasma total HC concentration and dementia scale [9]. We recently reported that the increased total HC concentration in the cerebrospinal fluid (CSF) of $\mathrm{AD}$ patients was of brain origin [10].

On the other hand, several studies have established an association of oxidative stress with AD. Oxidative damage results from an impaired oxidative balance in which the reactive oxygen production exceeds cellular antioxidant defenses, leading to damage to proteins, lipids and nucleic acids [11]. The free radical theory of aging suggests a major role for oxidative stress in age-related cellular dysfunction. The central nervous system is particularly vulnerable to oxidative damage because of its higher energy requirements, higher oxygen consumption rate and less active antioxidant defense system as compared to other organs [12]. Increases in the production of nitric oxide and 3-nitrotyrosine, an oxidative stress marker of peroxynitrite, have been reported in various neurodegenerative disorders including AD $[13,14]$ and in normal aging [14]. Several studies, mainly using cultured cell lines, have also shown that apoptosis is caused when $\beta$-protein is added to neuronal cultured cells. The mechanism for this is believed to be the reduction of $\beta$-protein to its elements by metal ions or hydrogen peroxide under oxidative conditions. This causes the production of reactive oxygen species and reactive nitrogen species $[15,16]$.

8 -Hydroxyguanosine (8-OHG) is a good marker of hydroxyl radical damage to RNA. This molecule has been proposed as a useful systematic marker of oxidative stress [17]. Since RNA is turned over rapidly, the level of 8-OHG reflects the steady-state oxidative balance at the time of determination rather than the previous oxidative damage $[18,19]$. Recent histochemical studies showed a marked accumulation of 8-OHG cytoplasmic RNA within the cerebral neurons of patients with AD [20].

We measured the CSF concentrations of free $\mathrm{HC}$, total $\mathrm{HC}$ and $8-\mathrm{OHG}$ in each specimen [10, 21]. Based on the in vivo findings, we reported that an increase in total HC and metabolites (such as homocysteic acid) [5] might be related to the pathogenesis of $\mathrm{AD}$ [10]. Moreover, we dem- 
onstrated the importance of RNA oxidation in the early phase of AD development [21].

In the present study, we measured free $\mathrm{HC}$, total $\mathrm{HC}$ and 8-OHG using the same sample as in the above-mentioned analysis in order to determine their concentrations in the CSF of patients with AD. We thus investigated whether $\mathrm{HC}$ contributes to RNA disorders in the pathogenesis of $\mathrm{AD}$.

\section{Materials and Methods}

\section{Patients}

The subjects were 18 untreated patients with $\mathrm{AD}(\mathrm{M} / \mathrm{F}=7 / 11)$ and 15 age-matched controls $(\mathrm{M} / \mathrm{F}=9 / 6)$, with a mean age $\pm \mathrm{SD}$ of $67.4 \pm 5.0$ and of $65.7 \pm 9.2$ years, respectively. The control subjects were neurologically normal patients who underwent lumbar spinal anesthesia for minor surgery. Diagnostic criteria for AD were defined according to the Diagnostic and Statistical Manual of Mental Disorders, 4th revision (DSM-IV) [22], the National Institute of Neurological and Communicative Disorder and Stroke (NINCDS), the AD and Related Disorders Association (ADRDA) [23] and Hachinski's ischemic score [24]. Cognitive function was assessed based on the Mini-Mental State Examination (MMSE) score [25]. In the patients with $\mathrm{AD}$, the duration of illness \pm SD was $3.1 \pm 2.2$ years and the mean MMSE score \pm SD $16.5 \pm 3.5$. All the patients were admitted to a hospital and were maintained on a standard diet. All the patients or their families provided informed consent, and the study protocol was approved by the Committee for Ethics in Biomedical Research at Iwate Medical University (Morioka, Japan).

\section{CSF Analysis}

CSF was obtained by lumbar puncture with the patients in a lateral decubitus position between 9.00 and 10.00 a.m., after overnight bed rest and before breakfast. For serum preparation, venous blood samples were centrifuged at $1,000 \mathrm{~g}$ for $5 \mathrm{~min}$ at $4^{\circ} \mathrm{C}$. First, a 3-ml CSF sample was used for general examination, and a further 1-ml CSF sample and serum samples taken from the patients were rapidly frozen and stored at $-80^{\circ} \mathrm{C}$ prior to being assayed. Cell counts and protein concentrations in CSF were within their normal ranges in both $\mathrm{AD}$ patients and controls $(1.6 \pm 1.1$ $\mathrm{mm}^{3}$ and $35.2 \pm 5.2 \mathrm{mg} / \mathrm{dl} ; 1.4 \pm 1.2 \mathrm{~mm}^{3}$ and $29.4 \pm 8.2 \mathrm{mg} / \mathrm{dl}$, respectively).

Free and Total HC

A tube filled with $100 \mu$ l of distilled water was used to determine the free $\mathrm{HC}$ concentration, and a tube filled with $75 \mu \mathrm{l}$ of distilled water and $25 \mu \mathrm{l}$ of Tris(2-carboxy-ethyl)phosphine to determine the total $\mathrm{HC}$ concentration. To each of these tubes, 300 $\mu \mathrm{l}$ of CSF was added. Then, $300 \mu \mathrm{l}$ was added after mixing for $60 \mathrm{~s}$ with a vortex mixer and shaking by hand for $10 \mathrm{~min}$, followed by the addition of $500 \mu \mathrm{l}$ of $0.3 \mathrm{~N} \mathrm{HClO}_{4}$. After shaking for $1 \mathrm{~min}$, $100 \mu \mathrm{l}$ was centrifuged at $25^{\circ} \mathrm{C}$ and $10,000 \mathrm{~g}$ for $10 \mathrm{~min}$. Finally, $100 \mu \mathrm{l}$ of supernatant was taken and $20 \mu \mathrm{l}$ of it applied to a highperformance liquid chromatography column $\left(\mathrm{MCM} \mathrm{C}_{18}\right.$ reversedphase column, $80 \times 4.6 \mathrm{~mm}$; MC Medical, Tokyo, Japan) with an electrochemical detector (Coulochem II Model 5300; ESA, Inc.,
Bedford, Mass., USA) system to determine the concentration of $\mathrm{HC}$. The electrode potentials were maintained at $750 \mathrm{mV}$ for detector II. The mobile phase consisted of $0.15 \mathrm{M}$ phosphate $(\mathrm{pH} 2.7)$ and phosphoric acid-methanol $(92 / 8 \mathrm{v} / \mathrm{v})$; buffered saline was used. The flow rate was $1.0 \mathrm{ml} / \mathrm{min}$, and the column temperature kept at $26^{\circ} \mathrm{C}$. The detection limits for free $\mathrm{HC}$ and total $\mathrm{HC}$ were both $0.1 \mathrm{nM}$. The standard of HC was obtained from Sigma Chemical Co. (St. Louis, Mo., USA).

\section{8-Hydroxyguanosine}

The free 8-OHG concentration was determined according to the method of Shigenaga et al. [26] with some modifications.

Briefly, $1 \mathrm{ml}$ of CSF or serum was absorbed in a solid-phase extraction cartridge (Bond Elut $\mathrm{C}_{18} 3 \mathrm{ml} / 200 \mathrm{mg}$; VARIAN, Harbor City, Calif., USA) and eluted with $1.5 \mathrm{ml}$ of methanol. The eluate was concentrated with a centrifugal evaporator and dissolved in $100 \mu \mathrm{l}$ of distilled water. After filtration with a $0.45-\mu \mathrm{m}$ membrane filter, $40 \mu$ l of the solution were analyzed using highperformance liquid chromatography (MCM $\mathrm{C}_{18}$ reversed-phase column, $250 \times 4.6 \mathrm{~mm}$; MC Medical) with an electrochemical detector (Coulochem II Model 5200; ESA, Inc.). The mobile phase consisted of $10 \mathrm{mM} \mathrm{NaH}_{2} \mathrm{PO}_{4}$ and $6 \%$ (for CSF) or $4 \%$ (for serum) methanol. The electrode potentials were maintained at $0.3 \mathrm{~V}$ for the guard cell, $0.15 \mathrm{~V}$ for detector I and $0.25 \mathrm{~V}$ for detector II. The flow rate was $1.0 \mathrm{ml} / \mathrm{min}$ and the column temperature was kept at $20^{\circ} \mathrm{C}$. The limit of detection for 8-OHG was $20 \mathrm{pM}$. The 8-OHG standard was obtained from Cayman Chemical Co. (Ann Arbor, Mich., USA).

\section{Statistical Analysis}

In brief, the statistical analysis was performed using the nonparametric Mann-Whitney U test or the Spearman rank correlation coefficient $\left(\mathrm{r}_{\mathrm{s}}\right)$ with Stat View 5.0 software (SAS Institute, Inc., Cary, N.C., USA). $\mathrm{p}<0.05$ was considered to be statistically significant.

\section{Results}

\section{Free and Total HC Concentrations in CSF}

The concentration of free $\mathrm{HC}$ did not differ significantly between controls $(10.9 \pm 3.4 \mathrm{nM})$ and AD patients $(10.6 \pm 6.0 \mathrm{nM})$. The concentration of total $\mathrm{HC}$ in $\mathrm{AD}$ patients $(110.6 \pm 31.6 \mathrm{nM})$ was significantly increased as compared to $84.9 \pm 24.5 \mathrm{nM}$ in controls $(\mathrm{p}<0.05)$ (table 1). There was no significant correlation between the duration of illness and the concentration of total $\mathrm{HC}$ in $\mathrm{AD}$. In patients with $\mathrm{AD}$, there was no significant correlation between MMSE score and the concentration of total HC [10].

\section{8-OHG Concentration in CSF}

The concentration of 8-OHG in the CSF of the control subjects ranged from 40 to $140 \mathrm{pM}$. There was no significant correlation of the $8-\mathrm{OHG}$ concentration with age 


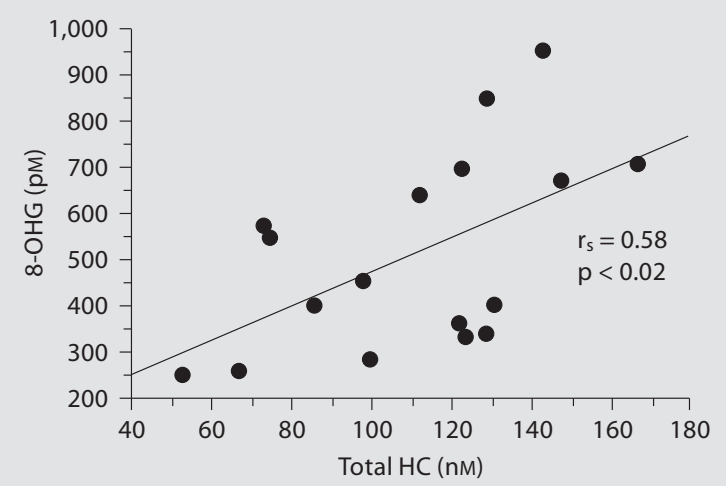

Fig. 2. Correlations between total $\mathrm{HC}$ and $8-\mathrm{OHG}$ in the CSF from patients with $\mathrm{AD}$.

Table 1. Concentrations of free HC and total HC in the CSF of patients with AD

\begin{tabular}{llc}
\hline & Free HC, nM & Total HC, nM \\
\hline Controls & $10.9 \pm 3.4$ & $84.9 \pm 24.5$ \\
AD patients & $10.6 \pm 6.0$ & $110.6 \pm 31.6^{*}(+31 \%)$ \\
\hline
\end{tabular}

Values are means \pm SD. ${ }^{*} \mathrm{p}<0.001$.

Table 2. Concentrations of $8-\mathrm{OHG}$ in serum and CSF of patients with AD

\begin{tabular}{lll}
\hline & 8-OHG in serum, nM & 8-OHG in CSF, pM \\
\hline Controls & $1.42 \pm 0.59$ & $97 \pm 32$ \\
AD patients & $1.53 \pm 0.60$ & $500 \pm 213^{*}(+>500 \%)$ \\
\hline
\end{tabular}

Values are means $\pm \mathrm{SD} .{ }^{*} \mathrm{p}<0.001$.

$\left(r_{s}=-0.25 ; p=0.35\right)$. The concentration of $8-O H G$ was significantly and remarkably increased in the CSF of the patients with $\mathrm{AD}$ as compared to the controls (500 \pm 213 vs. $97 \pm 32$ pM; $p<0.001$ ) (table 2). The difference between the groups was clear: each of the $18 \mathrm{AD}$ patients had a concentration of $8-\mathrm{OHG}$ that was $>250 \mathrm{pM}$. The concentration of $8-\mathrm{OHG}$ in the CSF of AD patients showed a significant negative correlation with the dura- tion of illness $\left(\mathrm{r}_{\mathrm{s}}=-0.48 ; \mathrm{p}<0.05\right.$; data not shown) and a significant positive correlation with the MMSE score $\left(r_{s}=0.67 ; p<0.01\right.$; data not shown $)$.

However, the concentration of 8-OHG in the CSF did not correlate with that in the serum of controls $\left(r_{s}=-0.10\right.$; $\mathrm{p}=0.71)$ or $\mathrm{AD}$ patients $\left(\mathrm{r}_{\mathrm{s}}=-0.12 ; \mathrm{p}=0.61\right)$. In addition, the concentration of 8-OHG in the serum of $\mathrm{AD}$ patients $(1.53 \pm 0.60 \mathrm{nM})$ was not significantly altered as compared to the controls $(1.42 \pm 0.59 \mathrm{nM})[21]$.

\section{Correlation between Total HC and 8-OHG \\ Concentrations in CSF}

We observed a significant positive correlation between total $\mathrm{HC}$ and 8-OHG concentrations in the CSF $\left(\mathrm{r}_{\mathrm{s}}=0.58\right.$; $\mathrm{p}<0.02$ ) (fig. 2). This relationship was not observed in controls (data not shown).

\section{Discussion}

The involvement of $\mathrm{HC}$ in $\mathrm{AD}$ has not been evaluated in autopsied brains, while in vivo studies have been performed on plasma total HC. Selley et al. [27] recently examined the CSF of 8 patients with $\mathrm{AD}$ and found that total $\mathrm{HC}$ in the CSF was high in AD patients, and that a positive correlation existed between the total $\mathrm{HC}$ concentration and the concentration of 4-hydroxy-2-nonenal, which is a biochemical marker of the neurotoxic products of lipid peroxidation. The results of that study suggest that $\mathrm{HC}$ may induce neuronal damage via oxidative stress [27]. HC has also been reported to enhance the susceptibility of the hippocampus to neuronal damage and may promote the peroxidation of amyloid $\beta$-protein (the major protein component in senile plaques) or enhance neurotoxicity [28].

Recently, we showed that total HC and HC metabolites such as homocysteic acid might be related to the pathogenesis of $\mathrm{AD}$. Based on these results, it appears that an increase in total $\mathrm{HC}$ in the brain characterizes $\mathrm{AD}$ and that total $\mathrm{HC}$ is a contributor to degeneration; however, this could also reflect an epiphenomenon [10].

We recently demonstrated a significant fivefold increase in 8-OHG concentration in the CSF of AD patients as compared to controls. But the concentration of 8-OHG in the CSF showed no correlation with that in the serum in both the controls and AD patients. In addition, the concentration of 8-OHG in the serum was not significantly altered in the $\mathrm{AD}$ patients compared to that in the controls, suggesting that the $8-\mathrm{OHG}$ concentrations in CSF do not reflect those in serum and may probably re- 
flect those in brain tissue. Also, we observed a negative correlation between the concentration of 8-OHG and the duration of illness as well as a positive correlation between the concentration of 8-OHG and the MMSE score [21]. Although we cannot specify the origin of 8-OHG in the CSF, its concentration in the CSF may, for the most part, reflect that in the brain rather than in the blood because $8-\mathrm{OHG}$ is hydrophilic. The concentrations of 8 OHG in serum showed no correlation with those in CSF in both the controls and AD patients. Further, the concentrations of 8-OHG in serum did not significantly differ between controls and AD patients.

The present data suggest the possibility that RNA oxidation is abnormally accelerated in the cerebral tissue of $\mathrm{AD}$ patients and that an increased oxidation of RNA occurs in the early stages of AD. These findings are consistent with those of previous reports on semiquantitative immunohistochemical studies using anti-8-OHG monoclonal antibody in autopsied brains [29]. These previous studies reported that $8-\mathrm{OHG}$ immunoreactivity was significantly increased in the hippocampus and in neurons within the frontal, temporal and occipital neocortex of $\mathrm{AD}$ brains compared with controls [29]. During aging, nerve cells in the cerebral cortex of patients with Down's syndrome demonstrate neuropathological changes similar to those found in $\mathrm{AD}[20,30]$.

Whether oxidative stress plays a role in the early phase of $\mathrm{AD}$ pathogenesis or is secondary to neuropathological changes in $\mathrm{AD}$ remains to be determined. RNA is more vulnerable to oxidative stress than DNA both in vitro and in vivo $[15,16]$ probably because, unlike nuclear DNA,
RNA is single-stranded and not covered with protective histones. The relative paucity of oxidative damage to DNA may be explained by a DNA repair mechanism, while the only known compensation for an increased oxidation of RNA is its higher turnover rate [17]. The fidelity of RNA, a molecule that can be viewed as the disposable soma of genetic information, has been much less studied than that of DNA, which is the heritable germ line. However, there may be unidentified RNA repair mechanisms that are involved in important RNA modifications such as editing and splicing [31]. Therefore, RNA oxidation is abnormally accelerated in the cerebral tissue of $\mathrm{AD}$ patients, and an increased oxidation of RNA occurs in the early stage of $\mathrm{AD}$.

In summary, the untreated $\mathrm{AD}$ patients showed that total $\mathrm{HC}$ and 8-OHG concentrations were elevated in the CSF. In addition, total $\mathrm{HC}$ and 8-OHG were significantly increased in the $\mathrm{AD}$ patients. Our results demonstrate a significant positive correlation between concentrations of total $\mathrm{HC}$ and 8-OHG in CSF. These findings suggest that RNA disorders due to associated $\mathrm{HC}$ may result from oxidative damage mediated by HC in the etiopathogenesis of $\mathrm{AD}$.

\section{Acknowledgments}

We wish to thank Miss Yoko Iwa for her technical and secretarial assistance. This study was supported in part by the Ministry of Education, Science and Culture, and the Ministry of Health, Labor and Welfare in Japan.

\section{References}

1 Seshadri S, Beiser A, Selhub J, Jacques PF, Rosenberg IH, D'Agostino RB, Wilson PW: Plasma homocysteine as a risk factor for dementia and Alzheimer's disease. N Engl J Med 2002;346:476-483.

-2 Starkebaum G, Harlan JM: Endothelial cell injury due to copper-catalyzed hydrogen peroxide generation from homocysteine. J Clin Invest 1986;77:1370-1376.

-3 Nishinaga M, Ozawa T, Shimada K: Homocysteine, a thrombogenic agent, suppresses anticoagulant heparin sulfate expression in cultured porcine aortic endothelial cells. J Clin Invest 1993;92:1381-1386.

$\checkmark 4$ Ueland PM: Homocysteine species as components of plasma redox thiol status. Clin Chem 1995;41:340-342.
Parnetti L, Bottiglieri T, Lowenthal D: Role of homocysteine in age-related vascular and non-vascular diseases. Aging (Milano) 1997; 9:241-257.

-6 Kruman II, Kumaravel TS, Lohani A, Pedersen WA, Cutler RG, Kruman Y, Haughey N, Lee J, Evans M, Mattson MP: Folic acid deficiency and homocysteine impair DNA repair in hippocampal neurons and sensitize them to amyloid toxicity in experimental models of Alzheimer's disease. J Neurosci 2002;22:1752-1762.

7 Frosst P, Blom HJ, Milos R, Goyette P, Sheppard CA, Matthews RG, Boers GJ, den Heijer M, Kluijtmans LA, van den Heuvel LP: A candidate genetic risk factor for vascular disease: a common mutation in methylenetetrahydrofolate reductase. Nat Genet 1995;10: 111-113.
Selhub J, Jacques PF, Wilson WF: Vitamin status and intake as primary determinants of homocysteinemia in an elderly population. JAMA 1993;270:2693-2698.

-9 Lehmann M, Gottfries CG, Regland B: Identification of cognitive impairment in the elderly: homocysteine is an early marker. Dement Geriatr Cogn Disord 1999;10:12-20.

10 Isobe C, Murata T, Sato C, Yasuo T: Increase of total homocysteine concentration in cerebrospinal fluid in patients with Alzheimer's disease and Parkinson's disease. Life Sci 2005;77:1836-1843.

11 Harman D: Aging: a theory based on free radical and radiation chemistry. J Gerontol 1956;11:298-300.

12 Floyd RA: Antioxidants, oxidative stress, and degenerative neurological disorders. Proc Soc Exp Biol Med 1999;222:236-245. 
-13 Smith MA, Harris RP, Sayre LM, Beckman JS, Perry G: Widespread peroxynitrite-mediated damage in Alzheimer's disease. J Neurosci 1997; 17:2653-2657.

14 Tohgi H, Abe T, Yamazaki K, Murata T, Ishizaki E, Isobe C: Alteration of 3-nitrotyrosine concentration in the cerebrospinal fluid during aging and in patients with Alzheimer's disease. Neurosci Lett 1999;269: 52-55.

15 Colton CA, Gilbert DL: Production of superoxide anions by a CNS macrophage, the microglia. FEBS Lett 1987;223:284-288.

$\checkmark 16$ Behl C, Davis JB, Lesley R, Schubert D: Hydrogen peroxide mediates amyloid beta protein toxicity. Cell 1994;77:817-827.

-17 Akama KT, Albanese C, Pestell RG, van Eldik LJ: Amyloid beta-peptide stimulates nitric oxide production in astrocytes through an NF- $\mathrm{B}$-dependent mechanism. Proc Natl Acad Sci USA 1998;95:5795-5800.

18 Dani SU: Molecular turnover and aging; in Dani SU, Hori A, Walter GF (eds): Principles of Neural Aging. Amsterdam, Elsevier, 1997, pp 83-101.

-19 Sayre LM, Perry G, Smith MA: In situ methods for detection and localization of oxidative stress: application in neurodegenerative disorders. Methods Enzymol 1999;309:133152 .
20 Nunomura A, Perry G, Aliev G, Hirai K, Takeda A, Balraj EK, Jones PK, Ghanbari H, Wataya T, Shimohama S, Chiba S, Atwood CS, Petersen RB, Smith MA: Oxidative damage is the earliest event in Alzheimer disease. J Neuropathol Exp Neurol 2001;60:759-767.

21 Abe T, Tohgi H, Murata T, Isobe C, Sato C: Remarkable increase in the concentration of 8-hydroxyguanosine in cerebrospinal fluid from patients with Alzheimer disease. JNeurosci Res 2002;70:447-450.

22 American Psychiatric Association: Diagnostic and Statistical Manual of Mental Disorders, ed 4 (DSM-IV). Washington, American Psychiatric Association Press, 1994, pp 135155.

-23 McKhann G, Drachman D, Folstein M, Katzman R, Price D, Stadlan EM: Clinical diagnosis of Alzheimer's disease: report of the NINCDS-ADRDA Work Group under the auspices of Department of Health and $\mathrm{Hu}$ man Services Task Force on Alzheimer's Disease. Neurology 1984;34:939-944.

24 Hachinski VC, Iliff LD, Zilhka E: Cerebral blood flow in dementia. Arch Neurol 1975; 32:632-637.

25 Folstein MF, Folstein SE, McHugh PR: MiniMental State: a practical method of grading the cognitive state of patients for the clinician. J Psychiatr Res 1975;12:189-198.

-26 Shigenaga MK, Aboujaoude EN, Chen Q, Ames BN: Assays of oxidative DNA damage biomarkers 8-oxo-2'-deoxyguanosine and 8 -oxoguanine in nuclear DNA and biological fluids by high-performance liquid chromatography with electrochemical detection. Methods Enzymol 1994;234:16-33.
27 Selley ML, Close DR, Stern SE: The effect of increased concentration of homocysteine on the concentration of $(E)$-4-hydroxy-2-nonenal in the plasma and cerebrospinal fluid of patients with Alzheimer's disease. Neurobiol Aging 2002;23:383-388.

28 White AR, Huang X, Jobling MF, Barrow CJ, Beyreuther K, Masters CL, Bush AI, Cappai R: Homocysteine potentiates copper- and amyloid beta peptide-mediated toxicity in primary neuronal culture: possible risk factor in the Alzheimer-type neurodegenerative pathways. J Neurochem 2001;76:5091520.

$>29$ Nunomura A, Perry G, Pappolla MA, Wade R, Hirai K, Chiba S, Smith MA: RNA oxidation is a prominent feature of vulnerable neurons in Alzheimer's disease. J Neurosci 1999;19:1959-1964.

30 Nunomura A, Perry G, Pappolla MA, Friedland RP, Hirai K, Chiba S, Smith MA: Neuronal oxidative stress precedes amyloid- $\beta$ deposition in Down syndrome. J Neuropathol Exp Neurol 2000;59:1011-1017.

31 Fiala ES, Conaway CC, Mathis JE: Oxidative DNA and RNA damage in the livers of Sprague Dawley rats treated with the hepatocarcinogen 2-nitropropane. Cancer Res 1989;49:5518-5522. 